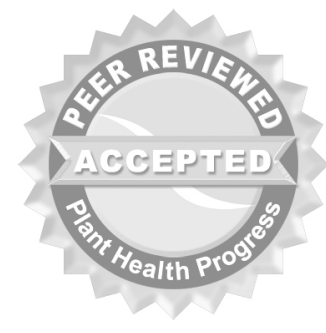

(c) 2007 Plant Management Network.

Accepted for publication 16 December 2006. Published 23 April 2007.

\title{
First Report of Melampsora euphorbiae on Poinsettia (Euphorbia pulcherrima) in Norway
}

\author{
H. B. Gjærum, V. Talgø, B. Toppe, M. L. Herrero, and A. \\ Stensvand, Norwegian Institute for Agricultural and Environmental \\ Research, Høgskoleveien 7, 1432 Ås, Norway
}

Corresponding author: V. Talgø. venche.talgo@bioforsk.no

Gjærum, H. B., Talgø, V., Toppe, B., Herrero, M. L., and Stensvand, A. 2007. First report of Melampsora euphorbiae on poinsettia (Euphorbia pulcherrima) in Norway. Online. Plant Health Progress doi: 10.1094/PHP-2007-0423-01-BR.

Melampsora euphorbiae (Schub.) Cast. is reported from all continents but Antarctica. The rust fungus is living on a great number of Euphorbia species. In Norway it is found on five Euphorbia species (wild growing or cultivated outdoors), including the common weed sun spurge (E. helioscopia L.). On this host the fungus is known in the country north to North Trøndelag County. To our knowledge M. euphorbiae on poinsettia (E. pulcherrima Willd.) has previously been reported only three times, namely in India (2), Tanzania (5), and Mauritius (1). M. euphorbiae-dulcis Otth. has been reported on poinsettia in Kenya (4). The fungus is autoecious, but has been found to have three specialized forms (3). None of them are reported on poinsettia. In September 2006, necrotic spots (Fig. 1 and 2) were observed on leaves of poinsettia cv. Cortez White from a greenhouse in Troms County in northern Norway. An examination of the spots revealed that they were caused by M. euphorbiae. Uredinia (Fig. 3) and telia (Fig. 4) were present in the material, both on the lower side of the leaves.

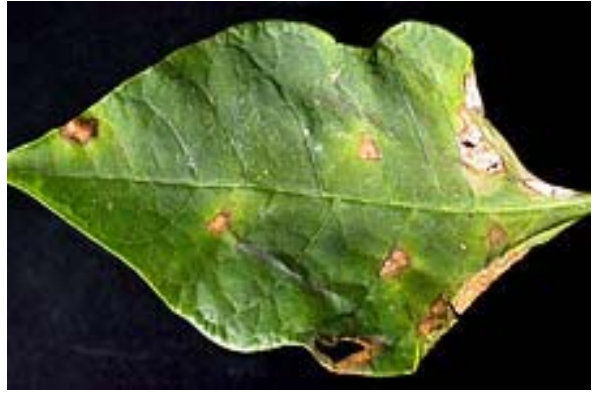

Fig. 1. Necrotic spots on the upper surface of a leaf of poinsettia (Euphorbia pulcherrima cv. Cortez White) infected with Melampsora euphorbiae. Photo by V. Talgø.

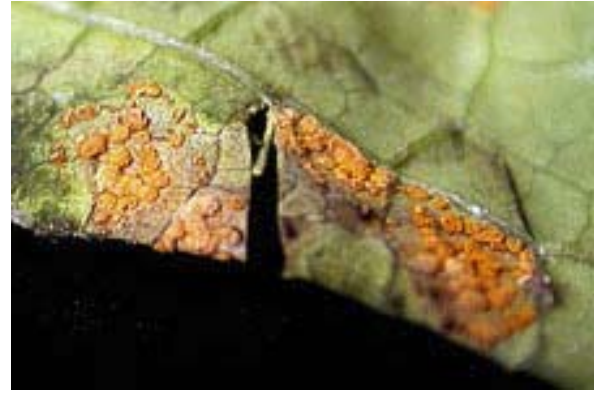

Fig. 2. Orange spore masses (urediniospores) of Melampsora euphorbiae on the lower surface of a leaf of poinsettia (Euphorbia pulcherrima cv. Cortez White). Photo by V. Talgø. 


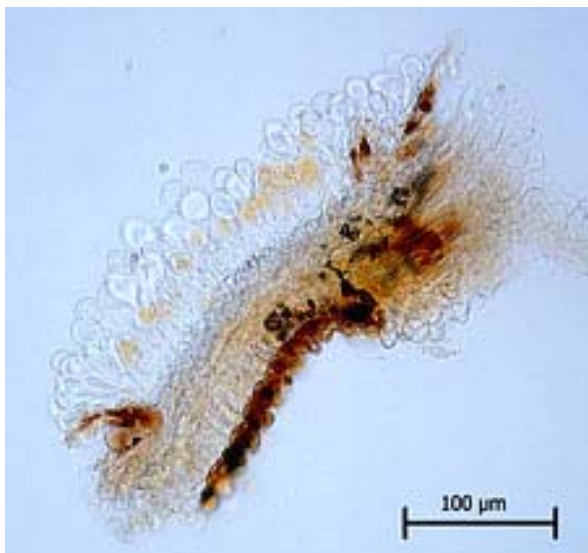

Fig. 3. Uredinia with paraphyses (round heads) and some urediniospores (orange, next to the paraphyses) of Melampsora euphorbiae on a cross section of an infected leaf of poinsettia (Euphorbia pulcherrima cv. Cortez White). Photo by M. L. Herrero.

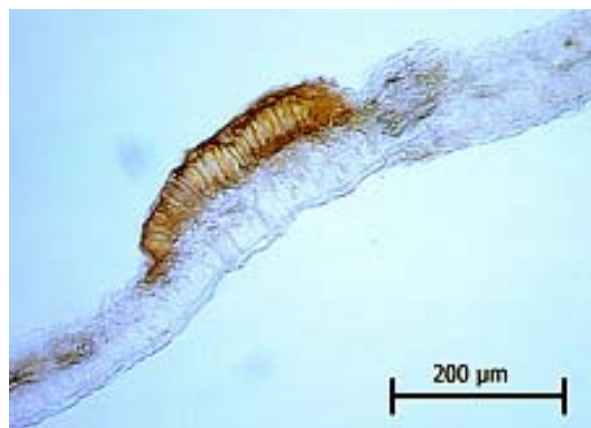

Fig. 4. Telia of Melampsora euphorbiae on a cross section of an infected leaf of poinsettia (Euphorbia pulcherrima cv. Cortez White). Photo by M. L. Herrero.

In October 2006, symptomatic leaves were collected from poinsettia cvs. Artic White, Cortez White, and Infinity Red at a greenhouse in North Trøndelag County that was the source of the infected plants in Troms County. Hence, a small survey was carried out in November and December 2006 in other nurseries that had received cuttings from the nursery in North Trøndelag. Positive samples were collected from five additional greenhouse locations. In total, M. euphorbiae was recorded on 11 cultivars by mid December 2006; Arctic White, Cortez White, Cortez Red, Infinity Red, Lilo, Malibu Red, Malibu White, Millennium, Prestige, Scandic, and Sonora. Cortez White was by far the most frequently and severely infected cultivar. Probably the initial infection started on this cultivar and therefore more time had been available to build up the infection level. Thus, other cultivars may not be more resistant than Cortez White. M. euphorbiae was found on up to 13 leaves per plant on Cortez White. Also some bracts were infected (Fig. 5).

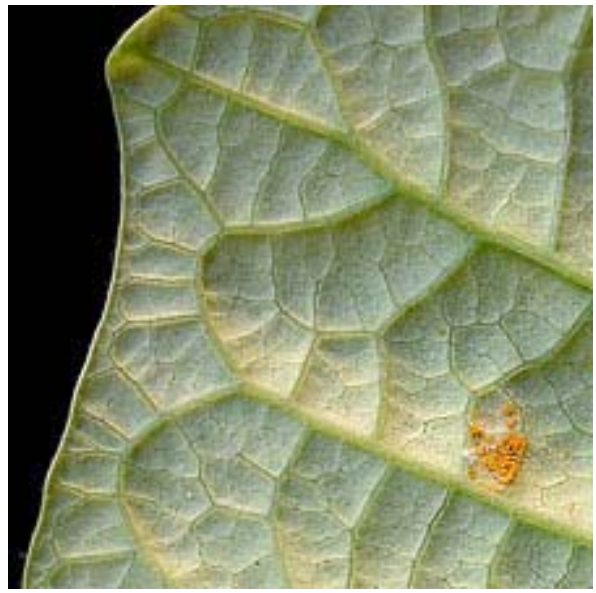

Fig. 5. Yellow-orange urediniospores of Melampsora euphorbiae on a bract of poinsettia (Euphorbia pulcherrima cV. Cortez White). Photo by V. Talgø.

The pale yellow necrotic spots on the upper surface of the leaves, often surrounded by a dark red margin, were scattered or confluent in small groups and reduced the commercial value of the plants considerably. 


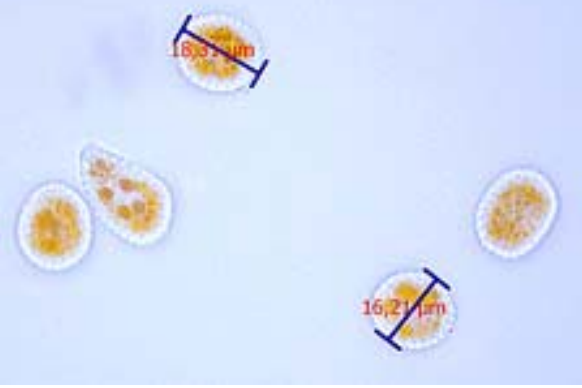

Fig. 6. Urediniospores of Melampsora euphorbiae from poinsettia (Euphorbia pulcherrima cv. Cortez White). Photo by M. L. Herrero.
The uredinia were 0.3 to $0.5 \mathrm{~mm}$ in diameter with capitate paraphyses. The heads of the paraphyses were 17.5 to $22.5 \mu \mathrm{m}$ in diameter and had hyaline walls that were apically thickened up to $6.5 \mu \mathrm{m}$. Urediniospores (Fig. 6) were 17.5-21.5 (26.5) × 15.0-19.0 $\mu \mathrm{m}$, subgloboid or ellipsoid with 1.5 to 2.5 $\mu \mathrm{m}$ thick hyaline and echinulate walls. On fresh material spore contents were yellow-orange.

A small number of subepidermal telial sori forming small, dark gray crusts were found close to the uredinia on a few leaves of Cortez White from three different greenhouse locations.

The one-celled teliospores were 27 to $55 \mu \mathrm{m}$ long and 13 to $16 \mu \mathrm{m}$ wide, with pale brown walls 1.0 to $1.5 \mu \mathrm{m}$ thick, apically thickened to $2.5 \mu \mathrm{m}$.

Poinsettia is the biggest flowering potted plant culture in Norway with approximately six million plants produced yearly. Most cuttings are from Norwegian stock plants, but a significant percentage is imported. Thus, it is not known whether the pathogen was introduced on imported cuttings or from infected Euphorbia spp. near the greenhouses.

\section{Acknowledgment}

We want to thank Norsk Gartnerforbund ("Norwegian growers association") for funding parts of this work.

\section{Literature Cited}

1. Anonymous. 1961. Plant Pathology. Rep. Dep. Agric. Mauritius, 1959:41-49. (Ref. Rev. Plant Path. 40:651).

2. Kala, S. P., and Gaur, R. D. 1983. Some new records of rust pathogens from Chamoli. Garhwal. Indian Phytopath. 36:757-758.

3. Müller, W. 1907. Versuche mit Uredineen auf Euphorbien und Hypericum.-Cbl. Bact. II, 17:210-211. Ref. E. Gäumann, 1959: Die Rostpilze Mitteleuropas. Buchdruckerei Büchler \& Co., Bern.

4. Nattrass, R. M. 1961. Host list of Kenya fungi and bacteria. Mycol. Papers, No. 81.

5. Wallace, G. B., and Wallace, M. W. 1949. A list of plant diseases of economic importance in Tanganyika Territory. Mycol. Papers No. 26. 